\title{
TARS Series of Cacao Germplasm Selections
}

\section{Ricardo Goenaga ${ }^{2}$, Heber Irizarry ${ }^{1}$, and Brian Irish \\ USDA-ARS, Tropical Agriculture Research Station (TARS), 2200 \\ P.A. Campos Avenue, Suite 201, Mayagüez, Puerto Rico 00680-5470}

Additional index words. Theobroma cacao, pod index, flavor

Cacao (Theobroma cacao L.) is an important component of small farming systems in the tropics. It adapts to a wide range of soils and climatic conditions, grows well under minimum tillage, adapts to temporary intercropping, has cash crop value in local and export markets, and pods are harvested yearround, providing a steady source of income.

World average cacao yield is low and was $522 \mathrm{~kg} \cdot \mathrm{ha}^{-1}$ in 2005 (Food and Agriculture Organization, 2007). In a commercial production system, it is highly recommended that cacao be propagated through the use of controlled-pollinated seed obtained from crosses of two or more productive parental clones (Batista, 1981; Wood and Lass, 1985). The use of this so-called "hybrid seed" is considered the simplest and cheapest method of cacao propagation and may offer the opportunity to assemble into a single tree useful traits from distant parents (Enriquez and Paredes, 1985; Enriquez and Soria, 1984; Willson, 1999). Other proponents also consider the use of controlled-pollinated seed as the most useful means of increasing cacao production (Hunter, 1990). In most cases, however, the data available to support the high yielding assumption attributed to controlled-pollinated seed is based only on the production obtained from a few unique segregating ' $F_{1}$ ' trees. Additionally, the yield data needed from long-term experiments to validate this assumption are not available. Lockwood et al. (2007) observed that the optimal strategy for clone selection is by family selection followed by evaluation of large numbers of clones drawn from superior families. There is a need to identify clones

Received for publication 17 Dec. 2008. Accepted for publication 9 Mar. 2009.

We thank Mr. Edward S. Seguine, Vice President, Research and Development/Quality Assurance, Guittard Chocolate Company, for the organoleptic evaluations of cacao samples.

This manuscript is dedicated to the memory of Nicolas Diaz, former Agricultural Science Research Technician, outstanding employee, and excellent human being.

Mention of trade names or commercial products in this publication is solely for the purpose of providing specific information and does not imply recommendation or endorsement of the U.S. Department of Agriculture.

${ }^{1}$ Retired Research Horticulturist.

${ }^{2}$ To whom reprint requests should be addressed; e-mail Ricardo.Goenaga@ars.usda.gov. with high yield potential for use by growers or in breeding programs (Warren, 1993). In this report, we describe the release of nine cacao clones selected for high yield during 4 years of production.

\section{Origin}

In a multisite (Corozal, Gurabo, Yabucoa) experiment in Puerto Rico, Irizarry and Rivera (1998) studied the yield potential of 1320 trees representing five interclonal cacao fullsib families (UF-668 $\times$ Pound-7, IMC-67 $\times$ UF-613, EET-400 $\times$ SCA-12, SCA-6 $\times$ EET62 , and IMC- $67 \times$ SCA-12) over a period of 8 years (1986 to 1993) of production at two locations and 4 years (1986 to 1989) at a third location (Table 1 ). Trees were $\approx 4$ years old when first harvested. All parental clones used in the generation of the full-sib families belong to various populations of the Forastero cacao group (Motamayor et al., 2008). The controlled-pollinated seed from these families was introduced from the Cacao Improvement Program at the 'Centro Agronómico Tropical de Investigación y Enseñanza' (CATIE), Turrialba, Costa Rica. The self-compatible parental clones possessed various levels of resistance against important cacao diseases (International Cocoa Germplasm Database, 2008) such as black pod disease (Phytophthora spp.), witches broom (Moniliophthora perniciosa), and vascular streak dieback (Oncobasidium theobromae) and were of frequent use in breeding programs at CATIE. Consequently, resultant seedlings were expected to have superior combining ability for higher yield and resistance to diseases. Single tree harvests were made throughout the experiments. The authors concluded that only $\approx 3 \%$ of the progeny in each family accounted for $\approx 60 \%$ of
$\mathrm{CEC}=$ cation exchange capacity. the total family yield. In a second experiment, Irizarry and Goenaga (2000) grafted scionwood from the 40 highest-yielding trees obtained from these families at the three locations above onto an open-pollinated rootstock (EET-400) with resistance to ceratocystis wilt (Ceratocystis fimbriata) and evaluated these clonal selections under full sunlight and intensive management at Corozal, Puerto Rico, during 4 years of production. Grafting plays an important role in the preservation of desirable genetic traits observed in cacao clonal selections and in maintaining homogeneity of the propagating materials (Paulin et al., 2007; Ramadasan and Ahmed, 1984). In addition to the 40 clones, five of the eight parental clones, UF-668, Pound-7, EET-400, SCA-12, and IMC-67, representing the original families (Irizarry and Rivera, 1998), were also grafted onto the same rootstock for comparison. Grafted clones were arranged in a randomized complete block design with six replications, each containing two experimental trees per treatment and evaluated during 4 years of production, 1994 to 1997, when trees were 3 to 6 years old. Organoleptic evaluation of $65 \%$ cacao-containing chocolate samples from the highest yielding clones was conducted at Guittard Chocolate Company, Burlingame, $\mathrm{CA}$, using the protocol of the $\mathrm{CFC} / \mathrm{ICCO} /$ INIAP Flavor Project (Sukha et al., 2008).

\section{Performance}

Of the 40 clones selected for final evaluation, only nine demonstrated superior yield when compared with either the combined mean of the five parental clones or the mean of their highest yielding parent (Table 2). For this reason, any potential negative effect of the rootstock on yield appeared negligible for these nine clones. These clones yielded an average of $2170 \mathrm{~kg} \cdot \mathrm{ha}^{-1}$ of dry beans per year during their first 4 years of full production and there were no significant yield differences among them. Clones TARS-1, TARS-9, TARS-23, and TARS-34 had lower pod index values than other clones (Table 2). A low pod index is normally associated with good bean size and a reduction in harvesting costs. None of the clones selected from families IMC-67 $\times$ SCA-12 and IMC-67 $\times$ UF-613 yielded more than the combined mean of the five parental clones or the individual mean of parents IMC-67 and

Table 1. Soil and weather characteristics at three cacao test sites in Puerto Rico.

\begin{tabular}{lccc}
\hline & \multicolumn{3}{c}{ Location } \\
\cline { 2 - 4 } Site characteristics & Corozal & Gurabo & Yabucoa \\
\hline Soil order & Ultisol & Inceptisol & Entisol \\
$\mathrm{pH}$ in water & 5.3 & 6.5 & 4.6 \\
$\mathrm{CEC}\left(\mathrm{cmol}(+) \cdot \mathrm{kg}^{-1}\right)$ & 10.9 & 33.50 & 3.8 \\
Elevation $(\mathrm{m})$ & 200 & 50 & 10 \\
Rainfall $(\mathrm{mm})$ & 1,840 & 1,700 & 2,274 \\
Class A pan evaporation & 1,410 & 1,678 & 1,796 \\
Temperature maximum $\left({ }^{\circ} \mathrm{C}\right)$ & 19.2 & 20.2 & 21.4 \\
Temperature minimum $\left({ }^{\circ} \mathrm{C}\right)$ & 30.0 & 31.6 & 30.2 \\
\hline
\end{tabular}


Table 2. Yield comparison of nine superior cacao clones and of five of their corresponding parental clones grown under full sunlight and intensive management in Puerto Rico during a 4-year harvesting period, 1994 to 1997

\begin{tabular}{llccc}
\hline $\begin{array}{l}\text { TARS clone } \\
\text { number }\end{array}$ & $\begin{array}{c}\text { Family pedigree or } \\
\text { parental clone }\end{array}$ & $\begin{array}{c}\text { Mean dry bean wt per } \\
\text { year }(\mathrm{kg} / \mathrm{tree})\end{array}$ & $\begin{array}{c}\text { Dry bean wt per } \\
\text { year }(\mathrm{kg} / \mathrm{ha})\end{array}$ & Pod index $^{\mathrm{z}}$ \\
\hline 14 & SCA-6 $\times$ EET-62 & $1.60 \mathrm{a}^{\mathrm{y}}$ & $2,400.0 \mathrm{a}$ & $36.6 \mathrm{c}$ \\
31 & SCA-6 $\times$ EET-62 & $1.54 \mathrm{a}$ & $2,310.0 \mathrm{a}$ & $43.3 \mathrm{~b}$ \\
34 & UF-668 $\times$ Pound-7 & $1.48 \mathrm{a}$ & $2,220.0 \mathrm{a}$ & $25.0 \mathrm{ef}$ \\
23 & UF-668 $\times$ Pound-7 & $1.45 \mathrm{a}$ & $2,175.0 \mathrm{a}$ & $24.5 \mathrm{ef}$ \\
27 & EET-400 $\times$ SCA-12 & $1.43 \mathrm{a}$ & $2,145.0 \mathrm{a}$ & $39.7 \mathrm{bc}$ \\
30 & SCA-6 $\times$ EET-62 & $1.43 \mathrm{a}$ & $2,145.0 \mathrm{a}$ & $40.4 \mathrm{bc}$ \\
9 & EET-400 $\times$ SCA-12 & $1.38 \mathrm{a}$ & $2,070.0 \mathrm{a}$ & $28.7 \mathrm{de}$ \\
15 & SCA-6 $\times$ EET-62 & $1.36 \mathrm{a}$ & $2,040.0 \mathrm{a}$ & $41.2 \mathrm{bc}$ \\
1 & UF-668 $\times$ Pound-7 & $1.35 \mathrm{a}$ & $2,025.0 \mathrm{a}$ & $25.4 \mathrm{ef}$ \\
& UF-668 & $0.94 \mathrm{~b}$ & $1,410.0 \mathrm{~b}$ & $22.0 \mathrm{f}$ \\
& SCA-12 & $0.85 \mathrm{bc}$ & $1,275.0 \mathrm{bc}$ & $31.0 \mathrm{~d}$ \\
& Pound-7 & $0.79 \mathrm{bc}$ & $1,185.0 \mathrm{bc}$ & $31.3 \mathrm{~d}$ \\
& EET-400 & $0.57 \mathrm{c}$ & $855.0 \mathrm{c}$ & $50.3 \mathrm{a}$ \\
& IMC-67 & $0.52 \mathrm{c}$ & $780.0 \mathrm{c}$ & $23.6 \mathrm{f}$ \\
& Mean of parental clones & 0.73 & $1,095.0$ & 31.6 \\
\hline
\end{tabular}

${ }^{\mathrm{z}}$ Total number of pods required to produce $1 \mathrm{~kg}$ of dried beans.

${ }^{\mathrm{y}}$ Means within a column followed by the same letter do not differ significantly with a Waller-Duncan $t$ test at the $0.01 P$ level.

Table 3. Chocolate flavor profiles of nine cacao clones selected for high yield in Puerto Rico during a 4-year harvesting period, 1994 to 1997.

\begin{tabular}{|c|c|}
\hline Clone & Flavor profile of $65 \%$ chocolate \\
\hline TARS-1 & $\begin{array}{l}\text { A very complex nut character comes through, more like chestnuts roasting with a blend of } \\
\text { some hazelnut skins }\end{array}$ \\
\hline TARS-9 & $\begin{array}{l}\text { Gorgeous color; very smooth in flavor profile; very mild chocolate notes up front with low } \\
\text { overall bitterness and a distinct nut character that persists; aftertaste has a residual nut/nut } \\
\text { skins note; really good chocolate }\end{array}$ \\
\hline TARS-14 & $\begin{array}{l}\text { Good base chocolate notes with a deep woody source; slight earthy, woodsy, and mushroom } \\
\text { notes; overall flavor comes off as quite good, very complex and very dark }\end{array}$ \\
\hline TARS-15 & $\begin{array}{l}\text { Very dark color; early mild astringency with an interesting wood resin/floral note that comes } \\
\text { through nicely; the late taste has an aldehyde, fruit character that is quite interesting; the } \\
\text { continuing aftertaste of the chocolate is very notable; complex floral/mild fruit note }\end{array}$ \\
\hline TARS-23 & $\begin{array}{l}\text { Rich, smooth chocolate profile up front with lots of deeper, mild dark wood notes; really } \\
\text { good overall flavor profile; the aftertaste is really a good chocolate }\end{array}$ \\
\hline TARS-27 & $\begin{array}{l}\text { Smoother flavor profile from the beginning with some very mild floral notes and some mild } \\
\text { chocolate cocoa; some mild spice notes along with slight flowers; the color is also a very } \\
\text { attractive brown, lighter brown hue }\end{array}$ \\
\hline TA & More of a woody late floral taste; astringency comes back at the aftertaste \\
\hline TARS-31 & $\begin{array}{l}\text { Interesting fruit tartness along with some astringency and a complex mildly floral with } \\
\text { tropical fruit notes }\end{array}$ \\
\hline TARS-34 & $\begin{array}{l}\text { Mild chocolate note with some mild fruit character; more of a fleshy yellow fruit flavor and } \\
\text { some mild brightness; acceptable flavor }\end{array}$ \\
\hline
\end{tabular}

SCA-12 (data not shown). A description of organoleptic characteristics of the nine high-yielding clones demonstrated wide diversity in flavor characteristics among clones (Table 3).

\section{Availability}

In 2002, scionwood of these nine clones was grafted onto Amelonado rootstock and trees have been established at the USDAARS cacao germplasm collection in Maya-

\section{Literature Cited}

Batista, L.J. 1981. Evaluación de la capacidad productiva de 6 híbridos de cacao en República Dominicana. Proc. 8th Int. Cocoa Res. Conf., Cartagena, Colombia. p. 713-717.

Enriquez, G.A. and A. Paredes. 1985. El cultivo del cacao. Serie: Cultivos mayores No. 4. Editorial. Univ. Estatal, San José, Costa Rica.

Enriquez, G.A. and J.V. Soria. 1984. Mejoramiento genético para resistencia a cinco enfermedades del cacao. Serie: Material de enseñanza No. 9. CATIE, Turrialba, Costa Rica.

Food and Agriculture Organization. 2007. FAOSTAT Statistics Database, 2005. July 2008. <http:// faostat.fao.org/site/497/default.aspx $>$.

Hunter, J.R. 1990. The status of cacao (Theobroma cacao, Sterculiaceae) in the Western hemisphere. Econ. Bot. 44:425-439.

International Cocoa Germplasm Database. 2008 ICGD online. February 2009. <http://www. icgd.rdg.ac.uk>

Irizarry, H. and R. Goenaga. 2000. Clonal selection in cacao based on early yield performance of grafted trees. J. Agr. Univ. P.R. 84:153-163.

Irizarry, H. and E. Rivera. 1998. Early yield of five cacao families at three locations in Puerto Rico. J. Agr. Univ. P.R. 82:163-171.

Lockwood, G., F. Owusu-Ansah, and Y. AduAmpomah. 2007. Heritability of single plant yield and incidence of black pod disease in cocoa. Exp. Agr. 43:455-462.

Motamayor, J.C., P. Lachenaud, J.W. da Silva e Mota, R. Loor, D.N. Kuhn, J.S. Brown, and R.J. Schnell. 2008. Geographic and genetic population differentiation of the Amazonian chocolate tree (Theobroma cacao L.). PLoS One 3:e3311.

Paulin, D., I. Garzon, and L. Alemanno. 2007. Clonal propagation by somatic embryogenesis: Preliminary results. Ingenic Newsletter 11:1619.

Ramadasan, K. and M.Y. Ahmed. 1984. Recent advances in vegetative propagation techniques of Theobroma cacao L. under Malaysian conditions. Proc. 8th Int. Conf. on Cocoa and Coconuts, Kuala-Lampur, Malaysia. p. 1-15.

Sukha, D.A., D.R. Butler, P. Umaharan, and E. Boult. 2008. The use of an optimal organoleptic assessment protocol to describe and quantify different flavour attributes of cocoa liquors made from Ghana and Trinitario beans. Eur. Food Res. Technol. 226:405-413.

Warren, J 1993. Cocoa breeding in the $21 \mathrm{st}$ century. Proc. of International Workshop on Conservation, Characterization, and Utilization of Cocoa Genetic Resources in the 21st Century. The University of the West Indies, Cocoa Research Unit, Port of Spain, Trinidad and Tobago, 13-17 Sept. 1992. St. Augustine, Trinidad, and Tobago. p. 215-220.

Willson, K.C 1999. Coffee, cocoa and tea. CABI Publishing, New York, NY. p. 100-110.

Wood, G.A.R. and R.A. Lass. 1985. Cocoa. 4th Ed. Longman Group Limited, London, UK. p. 80-92. 